\title{
Effect of Partial and Complete Replacement of Fishmeal with Mushroom Stalk Meal and Soy Bean Meal on Growth Performance of Nile Tilapia, Oreochromis niloticus Fingerlings
}

(Kesan Penggantian Separa dan Penuh Makanan Ikan dengan Tepung Batang Cendawan dan Tepung Kacang Soya ke atas Perkembangan Tumbesaran Anak Ikan Tilapia Nil Oreochromis niloticus)

\author{
HASNIYATI MUIN*, NORHIDAYAH MOHD TAUFEK, RAJI AMEENAT ABIODUN, \\ HANAN MOHD YUSOF \& SHAHARUDIN ABDUL RAZAK
}

\begin{abstract}
A dietary study was conducted to assess the use of mushroom stalk (MM), Pleurotus sajor caju, an agriculture waste and soy bean meal (SBM) as partial and complete replacement of fishmeal (FM) in tilapia fingerling diets. The study was conducted for 56 days. The diets were processed into sinking pellets. The experimental diets were formulated to replace fish meal protein at 0, 33, 67 and 100\% (diet 4, 3, 2 and 1). In this experiment, Nile tilapia fingerlings weighing about $1.00 \mathrm{~g}$ were fed each of four isonitrogenous diet. They were randomly distributed into 12 plastic tanks with each tank stocking 20 fish. The experiment was conducted in three replicates for each treatment. All the diets were well accepted by the fish. No physical abnormalities were observed in all treatments. Good growth performance was shown in $33 \%$ replacement (diet 3) of FM diet. However, diet 1 (100\% replacement) gave the highest increment in crude protein level and the best result of feed conversion ratio (FCR) and protein efficiency ratio (PER). Furthermore, the $100 \%$ replacement of FM (diet 1) was the best with a production cost of $R M 2.61 / \mathrm{kg}$.
\end{abstract}

Keywords: Fish feed; mushroom stalk; Oreochromis niloticus; Pleurotus sajor caju; soy bean meal

\section{ABSTRAK}

Suatu kajian pemakanan telah dijalankan untuk mengkaji penggunaan tepung batang cendawan (MM), Pleurotus sajor caju dan tepung kacang soya (SBM) sebagai bahan ganti separa dan penuh kepada tepung ikan (FM) di dalam makanan anak ikan tilapia. Kajian ini dijalankan selama 56 hari dan pelet makanan yang dihasilkan ialah jenis pelet tenggelam. Diet diformulasikan untuk menggantikan protein daripada FM pada kadar penggantian 0, 33, 67 dan 100\% (diet 4, 3, 2 dan 1). Kajian ini menggunakan anak ikan tilapia Nil seberat lebih kurang $1.00 \mathrm{~g}$. Anak-anak ikan ini diletak di dalam tangki plastik dan setiap tangki mengandungi 20 ekor anak ikan yang dipilih secara rawak. Keempat-empat diet telah diterima dengan baik oleh semua anak ikan. Tiada kecacatan fizikal direkodkan. Kadar pertumbuhan yang baik pula ditunjukkan pada diet yang mengandungi 33\% penggantian FM. Walau bagaimanapun, diet 1 menunjukkan kenaikan kadar protein yang tinggi dan juga FCR dan PER yang terbaik. Selain itu, diet 1 juga merupakan diet yang termurah dengan kos penghasilan adalah sebanyak RM2.61/kg.

Kata kunci: Makanan ikan; Oreochromis niloticus; Pleurotus sajor caju; tepung batang cendawan; tepung kacang soya

\section{INTRODUCTION}

Fish meal (FM) is considered to be the best ingredient as a main source of protein in fish feed as it is compatible with the protein requirement of fish (Alam et al. 1996). Due to this fact, it is not surprising that FM is the most expensive protein source in animal and aquaculture feeds (Tacon 1993). Increasing demand, unstable supply and high price of fish meal (FM) in tandem with the expansion of aquaculture industry made it necessary to search for alternative protein sources (FAO 2004; Lunger et al. 2007). Alternatives to FM can include fishery by-products, terrestrial animal by-products and plant protein sources. Formerly, many studies have considered soy bean meal as a partial or total fish meal replacement for tilapia due to its cheap price, ready availability, consistent quality with high protein content and good amino acid profile (Gatlin et al. 2007; Hardy 2006; Storebakken et al. 2000). However, recently the increasing price of soy bean meal in the market has led to the search for other much cheaper alternative protein sources in fish feed.

Pleurotus spp. is commonly known as oyster mushroom (Hassan et al. 2011). It can be found naturally in tropical and subtropical rainforests and can be artificially cultivated (Maziero et al. 1992). Mushrooms were consumed for their palatability and nutritional value in many countries worldwide. They were also consumed as a functional food to enhance health. The presence of B-glucan in mushrooms can be used as a prebiotic in 
human food and animal feeds (Jabir et al. 2012). Prior to this study, another mushroom species, Pleurotus florida was used to replace rice bran in diet for Clarias gariepinus and Oreochromis niloticus. It was observed that $100 \%$ of rice bran could be replaced by Pleurotus florida without sacrificing growth performance which led to a cheaper fish diet (Muin et al. 2014, 2013).

The aim of this study was to investigate the effect of substituting FM, an animal protein source with a less expensive plant protein source, Pleurotus sajur caju (mushroom meal) and soy bean meal on the growth performance of Nile tilapia Oreochromis niloticus.

\section{MATERIALS AND METHODS}

\section{EXPERIMENTAL DIETS}

Fresh mushroom stalk was obtained locally from a commercial mushroom farm. After harvesting, the stalk was immediately dried in an oven at $100^{\circ} \mathrm{C}$ overnight and then grinded. All the main raw materials including soy bean meal and mushroom stalk meal were analyzed for its proximate composition using the standard method according to AOAC (2002) for dry matter, moisture, crude protein, lipid and ash content. All the four experimental diets were formulated using the Winfeed (version 2.8) computer program based on isonitrogenous crude protein
(34\%) content. Formulated diets are shown in Table 1. Diet 1 substituted $100 \%$ FM, diet 2 substituted $67 \%$ FM, diet 3 substituted 33\% FM and diet 4 substituted $0 \%$ FM. The diets were made using a 'mini pelleting machine' to produce sinking and standard-sized pellets of $2.0 \mathrm{~mm}$ in diameter. All the diets were then dried in an oven at $100^{\circ} \mathrm{C}$ overnight and then stored in a cool and dry room to avoid contamination. Proximate analysis of each diet was carried out and the result is shown in Table 2.

\section{FEEDING TRIAL}

The fish were obtained from the Freshwater Fish Breeding Centre, Bukit Tinggi, Pahang, Malaysia. Prior to the feeding trial, the fish were acclimatized for one week and were fed with commercial pellet (35\% crude protein content). After being acclimatized, before the start of the experiment, the fish were fasted for $24 \mathrm{~h}$ and fish with similar sizes were randomly chosen and weighed. They were then randomly distributed into 12 plastic tanks. Each tank was stocked with 20 fish. Each diet was assigned to triplicate tanks. Several fish were frozen in the freezer for proximate analysis.

Twelve rectangular plastic tanks were used in an 8 -week experiment. Each tank was rectangular in shape $(24 \times 29 \times 39 \mathrm{~cm})$ complete with filtration and aeration. About $50 \%$ of the water in each tank was changed daily after first feeding in order to maintain the water quality.

TABLE 1. Diet formulation

\begin{tabular}{lcccc}
\hline Ingredients & Diet 1 & Diet 2 & Diet 3 & Diet 4 \\
\hline Fishmeal & 0 & 10 & 20 & 30 \\
Mushroom stalk & 30 & 20 & 10 & 0 \\
Soy bean meal & 49.05 & 47.78 & 37.02 & 26.25 \\
Rice bran & 1.04 & 0.32 & 12.51 & 26.25 \\
Corn starch & 13.96 & 15 & 15 & 15 \\
Palm oil & 3.45 & 4.4 & 2.97 & 1.55 \\
Premix vitamin $^{1}$ & 1 & 1 & 1 & 1 \\
Premix mineral $^{2}$ & 0.5 & 0.5 & 0.5 & 0.5 \\
Dcp & 1 & 1 & 1 & 1 \\
\hline Total & 100 & 100 & 100 & 100 \\
\hline
\end{tabular}

'vitamin A 50.000 MTV; Vitamin D3 10.000 MTV; Vitamin E $75.000 \mathrm{~g}$; Vitamin K3 $20.000 \mathrm{~g}$; vitamin B1 $10.000 \mathrm{~g}$; vitamin B2 $30.000 \mathrm{~g}$; vitamin B6 $20.000 \mathrm{~g}$; Vitamin $120.100 \mathrm{~g}$; calcium D- pantathenate $60.000 \mathrm{~g}$; nicotinic acid $200.000 \mathrm{~g}$; folic acid $5.000 \mathrm{~g}$; and blotin $235.000 \mathrm{~g}$ ${ }^{2}$ selenium $0.200 \mathrm{~g}$; iron $80.000 \mathrm{~g}$; manganese $100.000 \mathrm{~g}$; zinc $80.000 \mathrm{~g}$; copper $15.000 \mathrm{~g}$; potassium chloride $4.000 \mathrm{~g}$; magnesium oxide $0.6000 \mathrm{~g}$; sodium bicarbonate $1.500 \mathrm{~g}$; iodine $1.000 \mathrm{~g}$; and cobait $0.250 \mathrm{~g}$

TABLE 2. Proximate analysis of diets

\begin{tabular}{|c|c|c|c|c|}
\hline & Diet 1 & Diet 2 & Diet 3 & Diet 4 \\
\hline Dry matter & 95.88 & 95.40 & 95.44 & 95.22 \\
\hline Protein & 29.52 & 31.39 & 32.28 & 33.90 \\
\hline Lipid & 4.60 & 5.86 & 5.53 & 4.81 \\
\hline Fiber & 1.03 & 4.93 & 5.62 & 6.06 \\
\hline Ash & 7.04 & 8.24 & 10.12 & 12.37 \\
\hline $\mathrm{NFE}^{1}$ & 57.81 & 49.58 & 46.45 & 42.86 \\
\hline Gross energy $^{2}$ & 447.33 & 436.00 & 425.09 & 412.72 \\
\hline
\end{tabular}

$\mathrm{NFE}=100-(\%$ protein $+\%$ lipid $+\%$ ash $+\%$ fiber $)$

${ }^{2}$ Gross energy (GE) was calculated as 5.65, 9.45, $4.1 \mathrm{kcal} / \mathrm{g}$ for protein, fat and NFE, respectively (NRC 1993) 
All the aquaria were cleaned fortnightly and the fish were fed only in the afternoon on cleaning day.

The fish were fed with four different diets twice daily at 9.00 am and $4.00 \mathrm{pm}$ at $10 \%$ of their body weight based on feeding regime recommended by Lim (1989). The pellets were crushed into small sizes using a pestle and mortar and were hand-fed to the fish during feeding time. The total experimental period was 56 days. The diet was not offered on the sampling days. About $30 \mathrm{~min}$ after each feeding, any uneaten feed residue was removed from the aquarium tanks in order to maintain the water quality. The amount of feed given was constantly monitored so as not to over or underfeed them.

\section{SAMPLING TECHNIQUE}

Mortality count was done every day in order to determine the survival rate in each treatment. Fish growth was determined once a week. Growth was measured in terms of increase in body weight and total length. All fish from each tank were measured for total length $(\mathrm{cm})$ and weight $(\mathrm{g})$.

\section{PROXIMATE ANALYSIS OF BODY COMPOSITION}

Initial body composition of fish was analyzed from fish samples frozen at the beginning of the experiment. At the end of the experiment, all the fish in the aquaria were sacrificed and analyzed for whole body composition using the standard method according to AOAC (2002).

\section{EVALUATION OF GROWTH PARAMETERS}

Fish growth performance and protein utilization were analyzed in terms of weight gain (WG), feed conversation ratio $(\mathrm{FCR})$, specific growth rate (SGR) and protein efficiency ratio (PER). These parameters were calculated as below:

WG is the final body weight - initial body weight; FCR is the dry matter feed intake / body mass gain; SGR is the (ln [final body weight] $-\ln$ [initial body weight] $) \times 100 /$ number of days and PER is the increase in fish biomass / protein consumed.

\section{STATISTICAL ANALYSIS}

Analysis was performed using the statistical package for the social science version 17.0 (SPSS 17.0). All the data were subjected to one-way analysis of variance (ANOVA) followed by a comparison of means using the Least Significant Difference (LSD) Test. All differences were regarded as significantly different at $p<0.05$ among treatment groups.

\section{RESULTS}

\section{GROWTH, SURVIVAL RATE AND EVALUATION OF GROWTH PARAMETER}

Initial stocking density of fish was 20 fish per aquarium tank. On the 56th day at the end of the experiment, survival rate of the fish fed with diet 2 was higher $(66.67 \%)$, followed by fish fed with diet 4 which was $61.67 \%$, diet 1 was $60 \%$ and the least was from diet 3 in which only $50 \%$ of fish remained in the aquarium tank.

The growth of fish was estimated by measuring body length from tip of the mouth to tail and also by measuring the body weight every week. The initial mean value of fish for diet 1 was $1.083 \pm 0.082 \mathrm{~g}$, diet 2 was $1.034 \pm 0.052 \mathrm{~g}$, diet 3 was $1.015 \pm 0.039 \mathrm{~g}$ and diet 4 was $0.997 \pm 0.027 \mathrm{~g}$. At the end of the experiment, the weight performance of fish fed with diet 2 was the highest $(7.123 \pm 0.556 \mathrm{~g})$, followed by diet 3 , diet 4 and diet 1 which were $7.110 \pm 0.284 \mathrm{~g}$, $7.040 \pm 1.115 \mathrm{~g}$ and $7.006 \pm 0.457 \mathrm{~g}$, respectively. There was no significant difference $(p>0.05)$ in terms of weight performance between all experimental diets. The summary for the growth performance and feed utilization of tilapia fed with different diets is shown in Table 3. For all growth parameters, there was no significant difference $(p>0.05)$ among all the diets. However, for weight gain (WG) and the specific growth rate (SGR), the fish fed with diet 3 was the highest compared with the other diets. While in terms of feed conversion ratio (FCR) and protein efficiency ratio, fish fed with diet 1 gave the best result followed by fish fed with diet 2 , diet 3 and diet 4 .

\section{PROXIMATE WHOLE BODY COMPOSITION}

Proximate analysis on the whole-body composition at the initial and final of the experiment for fish fed with four different diets is shown in Table 4. There was significant difference $(p<0.05)$ for crude protein in body composition among all the fish fed with the different diets. The initial body composition for crude protein content of the fish

TABLE 3. Performance of tilapia fed with four different diets

\begin{tabular}{lcccc}
\hline & Diet 1 & Diet 2 & Diet 3 & Diet 4 \\
\hline Initial weight (g/fish) & $1.083 \pm 0.082^{\mathrm{a}}$ & $1.034 \pm 0.052^{\mathrm{a}}$ & $1.015 \pm 0.039^{\mathrm{a}}$ & $0.997 \pm 0.027^{\mathrm{a}}$ \\
Final weight (g/fish) & $7.060 \pm 0.457^{\mathrm{a}}$ & $7.123 \pm 0.556^{\mathrm{a}}$ & $7.110 \pm 0.284^{\mathrm{a}}$ & $7.040 \pm 1.115^{\mathrm{a}}$ \\
Body weight gain (g) & $5.924 \pm 0.479^{\mathrm{a}}$ & $6.089 \pm 0.597^{\mathrm{a}}$ & $6.095 \pm 0.280^{\mathrm{a}}$ & $6.042 \pm 1.142^{\mathrm{a}}$ \\
Specific growth rate (SGR) & $3.814 \pm 0.216^{\mathrm{a}}$ & $3.941 \pm 0.254^{\mathrm{a}}$ & $3.973 \pm 0.102^{\mathrm{a}}$ & $3.939 \pm 0.371^{\mathrm{a}}$ \\
Feed conversion ratio (FCR) & $3.351 \pm 0.093^{\mathrm{a}}$ & $3.362 \pm 0.204^{\mathrm{a}}$ & $3.390 \pm 0.067^{\mathrm{a}}$ & $3.654 \pm 0.302^{\mathrm{a}}$ \\
Protein Efficiency ratio (PER) & $0.200 \pm 0.015^{\mathrm{a}}$ & $0.197 \pm 0.019^{\mathrm{a}}$ & $0.190 \pm 0.010^{\mathrm{a}}$ & $0.177 \pm 0.033^{\mathrm{a}}$ \\
\hline
\end{tabular}

All the values are means \pm SE for triplicate feeding groups. Means on the same row with different superscripts are significantly different $(p<0.05)$ 
was $82.83 \pm 0.38 \%$. Diet 1 (100\% replacement of fish meal) gave the highest increment in crude protein level, followed by fish fed with diet 2 , diet 3 and diet 4 , which were $87.21 \pm 0.32,86.44 \pm 0.18,85.58 \pm 0.06$ and $83.01 \pm 0.43$, respectively.

\section{WATER QUALITY}

Table 5 shows the $\mathrm{pH}$, dissolved oxygen, ammonia concentration, nitrite and temperature of the culture water for each experimental diet throughout the culture period of 49 days. The range of $\mathrm{pH}$ for all diet was from 6.53 to 6.74, temperature from 29.33 to $29.54^{\circ} \mathrm{C}$, dissolved oxygen from 4.34 to 4.75 , total ammonia from 0.066 to $0.106 \mathrm{mg} / \mathrm{L}$ and total nitrate concentration from 0.206 to $0.246 \mathrm{mg} / \mathrm{L}$. There was no significant different in all the parameters for all the diets $(p>0.05)$ during the whole experimental period. This result indicated that the diets did not affect the quality of water in all experimental aquaria.

\section{COST OF EACH TYPE OF DIET}

An economic evaluation indicated that diet 1 gave the lowest production cost at RM2.61/kg followed by diet 2 , diet 3 and diet 4 at RM2.95/kg, RM3.14/ kg and RM3.33/ kg, respectively. Table 6 shows the cost per $\mathrm{kg}$ of the diets.

\section{DISCUSSION}

In this study, there was no significant difference $(p>0.05)$ between all the diets in terms of fish growth performance and protein utilization. All the fish fed with the four different diets showed almost similar growth performance and protein utilization. However, the fish fed with diet 3 which had $65 \%$ replacement of FM gave the best WG and SGR which were $6.095 \pm 0.280 \mathrm{~g}$ and $3.973 \pm 0.102 \mathrm{~g}$, respectively. Fish fed with diet 1 with $0 \%$ replacement of FM showed the best result with $3.351 \pm 0.093$ FCR and $0.200 \pm 0.015$ PER values, respectively. This means that the dietary protein level did not markedly affect the growth performance and feed utilization of the Nile tilapia.

Previous studies reported that growth performance of Nile tilapia in all weight classes are directly related to the dietary protein level in the feeds used. Based on the results obtained by Abdel-Tawwab et al. (2010), the optimum dietary protein required for Nile tilapia is weight dependent. Tilapia fries $(\sim 0.5 \mathrm{~g})$ required $45 \%$ of crude protein content in its diet for optimal growth while the fingerlings $(\sim 20 \mathrm{~g})$ and advanced juveniles $(\sim 40 \mathrm{~g})$ performed optimally well with $35 \%$ of crude protein content in their diets. El-Sayed and Teshima (1991) found that the protein requirement of Nile tilapia ranged between 20 and 56\% crude protein. Balarin and Haller (1982) reported that tilapia fries required a diet ranging between 35 and $50 \%$ crude protein and the 5 to $25 \mathrm{~g}$ fish needed between 25 and $35 \%$ of crude protein in their diets. The study of Tacon (1987) showed that the dietary protein levels varying from 42 to $35 \%$ is needed for the growth of adults of omnivorous fish species.

The variations in dietary crude protein needs related to fish weight may be attributed to different protein

TABLE 4 . Whole body proximate composition (\% fresh weight basis) at initial and final periods of experimentation with different diets

\begin{tabular}{lccccc}
\hline & Initial & Diet 1 & Diet 2 & Diet 3 & Diet 4 \\
\hline Moisture (\%) & $82.50 \pm 0.07^{\text {bc }}$ & $82.10 \pm 0.30^{\mathrm{b}}$ & $82.64 \pm 0.39^{\mathrm{bc}}$ & $83.50 \pm 0.28^{\mathrm{d}}$ & $80.81 \pm 0.35^{\mathrm{a}}$ \\
Protein $(\%)$ & $82.83 \pm 0.38$ & $87.21 \pm 0.32^{\mathrm{c}}$ & $86.44 \pm 0.18^{\mathrm{bc}}$ & $85.58 \pm 0.06^{\mathrm{b}}$ & $83.01 \pm 0.43^{\mathrm{a}}$ \\
\hline
\end{tabular}

All the values are means SE for duplicate feeding groups. Means on the same row with different superscripts are significantly different $(p<0.05)$

TABLE 5. Water quality parameter during experimental period

\begin{tabular}{lcccc}
\hline Components & Diet 1 & Diet 2 & Diet 3 & Diet 4 \\
\hline DO $(\mathrm{mg} / \mathrm{L})$ & $4.747 \pm 0.328^{\mathrm{a}}$ & $4.426 \pm 0.209^{\mathrm{a}}$ & $4.343 \pm 0.188^{\mathrm{a}}$ & $4.477 \pm 0.261^{\mathrm{a}}$ \\
Ph & $6.739 \pm 0.097^{\mathrm{a}}$ & $6.531 \pm 0.087^{\mathrm{a}}$ & $6.533 \pm 0.095^{\mathrm{a}}$ & $6.670 \pm 0.150^{\mathrm{a}}$ \\
Tempt $\left({ }^{\circ} \mathrm{C}\right)$ & $29.543 \pm 0.092^{\mathrm{a}}$ & $29.436 \pm 0.122^{\mathrm{a}}$ & $29.392 \pm 0.265^{\mathrm{a}}$ & $29.333 \pm 0.115^{\mathrm{a}}$ \\
NH4 $(\mathrm{mg} / \mathrm{L})$ & $0.084 \pm 0.337^{\mathrm{a}}$ & $0.066 \pm 0.028^{\mathrm{a}}$ & $0.106 \pm 0.033^{\mathrm{a}}$ & $0.087 \pm 0.025^{\mathrm{a}}$ \\
Nitrate $(\mathrm{mg} / \mathrm{L})$ & $0.238 \pm 0.022^{\mathrm{a}}$ & $0.246 \pm 0.015^{\mathrm{a}}$ & $0.206 \pm 0.034^{\mathrm{a}}$ & $0.245 \pm 0.014^{\mathrm{a}}$ \\
\hline
\end{tabular}

All the values are means \pm SE for triplicate feeding groups. Means on the same row with different superscripts are significantly different $(p<0.05)$

TABLE 6. Cost analysis of diets fed to Tilapia fingerlings

\begin{tabular}{lcccc}
\hline & Diet 1 & Diet 2 & Diet 3 & Diet 4 \\
\hline Diet cost $(\mathrm{RM} / \mathrm{kg})$ & 2.61 & 2.95 & 3.14 & 3.33 \\
Profit index $^{1}$ & 2.22 & 1.97 & 1.85 & 1.74 \\
\hline
\end{tabular}

Market price of fish: RM5.80/kg. profit index: value of fish/cost of feeding 
needs at different life history stages. The dietary protein requirements decreased with increasing fish weight and age (El-Sayed \& Teshima 1991). Besides, feed utilization was significantly affected by protein level and fish weight. FCR increased with fish weight. This has been reported by AlHafedh (1999), Abdelghany (2000), Khattab et al. (2000) and Siddiqui et al. (1988).

For the whole body composition, there was significant difference $(p<0.05)$ among all fish fed with all the diets. The crude protein content of fish fed with diet 1 with $0 \%$ replacement of FM was significantly the highest (87.21\%), followed by fish fed with diet $2(86.44 \%)$, diet $3(85.58 \%)$ and diet $4(83.01 \%)$. This corresponds well with the protein efficiency ratio (PER) value of all diets, in which diet 1 showed the highest value followed by diet 2, 3 and 4 which were $0.200 \pm 0.015,0.197 \pm 0.019,0.190 \pm 0.010$ and $0.177 \pm 0.033$, respectively. The data showed that the carcass composition was not clearly affected by diet composition. These findings are in agreement with Jabir et al. (2011), who reported that Nile tilapia fed with various level of super worm meal (SWM) did not significantly affect the whole body composition of experimental fish.

From previous study, Abdel-Tawwab et al. (2010) reported that the carcass proximate analysis of all weight classes was significantly influenced by dietary protein level and fish weight. Nile tilapia fed with $25 \%$ crude protein diet had lower content of protein than fish fed with $35 \%$ or $45 \%$ crude protein content diet for all weight classes. There was significant difference $(p<0.05)$ in terms of survival rate among all the diets. Fish fed with diet 2 $(66.67 \%)$ had the highest survival rate followed by diet $4(61.67 \%)$, diet $1(60 \%)$ and diet $3(50 \%)$. Although the fish fed with diet 3 showed better growth performance, in terms of survival rate it was the lowest where only $50 \%$ fish survived. In this study, there was no clear relationship between the experimental diets and the survival rates of all the fish. Several factors may affect the survival rate of fish fed with the experimental diets. At the beginning of the experiment, decrease in survival of fish may be due to changes in environmental conditions from natural to experimental. Daily water change was at $50 \%$ volume in order to maintain the water quality and to avoid causing stress to the fish. The mortality of fish occurring in all the treatments could be due to stress during handling and sampling of the fish.

The tilapia fish were fed twice a day as frequency of feeding could also affect the growth of fish. Based on Lim (1989), however, the best feeding frequency for tilapia weighing 1 to $5 \mathrm{~g}$ was 8 times per day and the feeding rate was 6 to $10 \%$ of body weight as size could influence feeding rates. It is generally known that younger fish require more energy for metabolism per unit body weight and have a faster growth rate than larger fish. Thus, smaller fish require more feed on a percent of body weight basis than larger fish.

All the pellet diets were crushed into smaller sizes using a pestle and mortar to ensure that all the feed were consumed by the fish. If the feed particles were too small or too large, they will not be efficiently consumed and will go to waste. In addition, the amount of nutrient leaching into the water will increase for smaller-sized feed (Lim \& Cuzon 1994).

\section{CONCLUSION}

The results obtained from this study showed almost similar growth performance and protein utilization. This shows that all the replacement diets could be used in tilapia practical diets. However, taking all factors into consideration (growth performance, feed utilization, whole body composition and cost of each diet), diet 1 (100\% replacement of fish meal) gives the best result. Hence, mushroom stalk has the potential to partially replace fishmeal in combination with soy bean meal and should be seriously considered as an alternative protein source to replace fishmeal in the making of cheaper fish feed.

\section{ACKNOWLEDGEMENTS}

We would like to thank the staff from the Freshwater Fisheries Research Centre, Glami lemi, Jelebu for their pellet-making assistance. Thanks are also due to Madam Cheng of Gano Farm Sdn. Bhd for supplying the mushroom stalks and Mr. Hafizul of Freshwater Fish Breeding Centre, Bukit Tinggi for supplying the tilapia fingerlings for use in this research. This study was supported by the University of Malaya Research Grant (UMRG, RP 005C-13AFR) to SAR.

\section{REFERENCES}

Abdelghany, A.E. 2000. Optimum dietary protein requirements for Oreochromis niloticus fry using formulated semi-purified diets. In Tilapia Aquaculture in the 21st Century Proceedings 5, edited by Fitzsimmons, K. \& Filho, J.C. Rio de Janeiro, Brazil, pp. 101-108.

Abdel-Tawwab, M., Mohammad, H.A., Yassir, A.E.K. \& Shalaby, A.M.E. 2010. Effect of dietary level, initial body weight, and their interaction on the growth, feed utilization, and physiological alterations of Nile tilapia, Oreochromis niloticus. Aquaculture 298: 267-274.

Alam, A.K., Maughan, E. \& Matter, W.J. 1996. Growth response of indigenous and exotic carp species to different protein sources in pelleted feeds. Aquaculture Research 27(9): 673-679.

Al-Hafedh, Y.S. 1999. Effects of dietary protein on growth and body composition of Nile tilapia, Oreochromis niloticus. Aquaculture Research 30(5): 385-393.

AOAC (Association of Official Analytical Chemists). 2002. Official Methods of Analysis. 13th Ed. Washington, D.C.: AOAC.

Balarin, J.D. \& Haller, R.D. 1982. The intensive culture of tilapia in tanks, race ways and cages. In Recent Advances in Aquaculture, edited by Muir, J.F. \& Roberts, R.J. London: Croom Helm. pp. 265-355.

El-Sayed, A.F.M. \& Teshima, S. 1991. Tilapia nutrition in aquaculture. Reviews in Aquatic Science 5: 247-265.

FAO (Food and Agriculture Organization of the United Nations). 2004. State of World fisheries and Aquaculture 2004. FAO, Rome, Italy. 
Gatlin, D.M. III., Barrows, F.T., Braown, P., Dabrowski, K., Gaylord, T.G., Hardy, R.W., Herman, E., Hu, G., Krogdahl, A., Nelson, R., Overturf, K., Rust, M., Sealy, W., Skonberg, D., Souza, E.J., Stone, D., Wilson, R. \& Wurtele, E. 2007. Expanding the utilization of sustainable plant products in aquafeeds: A review. Aquaculture Research 38: 551-579.

Hardy, R.W. 2006. Worldwide fish meal production outlook and the use of alternative protein meals for aquaculture. VIII International Symposium on Aquaculture Nutrition, November 15-17, Universidad Autonoma de Leon, Monterry, Leon, Mexico.

Hassan, S., Mohamad, A.Y. \& Kiramat, K. 2011. Cultivation of the oyster mushrooms Pleurotus ostreatus (Jacq.) P. Kummil in two different agroecological zones of Pakistan. African Journal of Biotechnology 10: 183-188.

Jabir, M.D.A.R., Razak, S.A. \& Vikineswary, S. 2012. Effect of mushroom supplementation as a prebiotic compound in super worm-based diet on growth performance of red tilapia fingerlings. Sains Malaysiana 41(10): 1197-1203.

Jabir, M.D.A.R., Razak, S.A. \& Vikineswary, S. 2011. Nutritive potential and utilization of Super Worm (Zophobas morio) meal in the diet of Nile tilapia (Oreochromis niloticus) juvenile. African Journal of Biotechnology 11(24): 65926598.

Khattab, Y.A.E., Ahmad, M.H., Shalaby, A.M.E. \& AbdelTawwab, M. 2000. Response of Nile tilapia from different locations to different dietary protein levels. Egypt Journal of Aquatic Biology and Fisheries 4: 295-311.

Lim, E.C. 1989. Practical Feeding - tilapias. In Nutrition and Feeding of Fish, edited by Lovell, T. New York: Van Nostrand Reinholt. pp. 163-183.

Lim, E.C. \& Cuzon, G. 1994. Water stability of shrimp pellet: A review. Asian Fisheries Science 7: 115-217.

Lunger, A.N., Mclean, E. \& Craig, S.R. 2007. The effect of organic protein supplementation upon growth, feed conversion and texture quality parameters in juvenile cobia. Aquaculture 264: 342-352.

Maziero, R., Bononi, V.L. \& Capelari, M. 1992. Cultivo e produtividade de Pleurotus ostreatus var. Florida em Mogi das Cruzes, SP, Brasil, Sao Paulo: Hoehnea. (In Spanish).

Muin, H., Fatah, N.N.A., Bahari, I.H. \& Razak, S.A. 2014. Replacement of rice bran with Pleurotus florida stalks on growth performance of Oreochromis niloticus fingerlings. Sains Malaysiana 43(5):675-681.

Muin, H., Fatah, N.N.A., Nor, M.H.M. \& Razak, S.A. 2013. Rice bran replacement in Clarias gariepinus fingerlings with Pleurotus florida stalk. Sains Malaysiana 42(8): 1109-1114.
NRC (National Research Council). 1993. Nutrient Requirement of Fish. National Academy Press, Washington DC.

Siddiqui, A.Q., Holder, M.S. \& Adam, A.A. 1988. Effects of dietary protein levels on growth, food conversion and protein utilization in fry and young Nile tilapia. Aquaculture 70: 63-73.

Storebakken, T., Refstie, S. \& Ruyter, B. 2000. Soy products as fat and protein sources in fish feeds for intensive aquaculture. In:Soy in Animal Nutrition, edited by Drackley, J.K. Savoy: Fed. Anim. Sci. Soc. pp. 127-170.

Tacon, A.G.J. 1993. Feed ingredients for warm water fish. Fish Meal and Other Processed Feedstuffs. FAO, Fish. Circ. No. 856, FAO, Rome, Italy. p. 64.

Tacon, A.G.J. 1987. The nutrition and feeding of farm fish and shrimp a training manual. The Essential Nutrients, FAO Brasilia Brazil, GCP/RLA/075/ITA Field Document 2/E. p.117.

Hasniyati Muin*, Norhidayah Mohd Taufek,

Raji Ameenat Abiodun \& Shaharudin Abdul Razak

AquaNutriBiotech Research Laboratory

Institute of Biological Sciences, Faculty of Science

University of Malaya

50603 Kuala Lumpur

Malaysia

Hasniyati Muin*, Norhidayah Mohd Taufek,

Raji Ameenat Abiodun \& Shaharudin Abdul Razak

Glami Lemi Biotechnology Research Centre

Glami Lemi, Titi

71650 Jelebu, Negeri Sembilan

Malaysia

Hanan Mohd Yusof

Freshwater Fisheries Research Division

Fisheries Research Institute, Glami Lemi

71650 Jelebu, Negeri Sembilan

Malaysia

*Corresponding author; email: Hasniyati_muin@yahoo.com

Received: 26 November 2013

Accepted: 31 October 2014 